Article

\title{
Impact of Harvest Conditions and Host Tree Species on Chemical Composition and Antioxidant Activity of Extracts from Viscum album L.
}

\author{
Wioleta Pietrzak*(D) and Renata Nowak (D)
}

check for updates

Citation: Pietrzak, W.; Nowak, R. Impact of Harvest Conditions and Host Tree Species on Chemical Composition and Antioxidant Activity of Extracts from Viscum album L. Molecules 2021, 26, 3741. https://doi.org/10.3390/ molecules26123741

Academic Editors: Silvie Rimpelová and John C. D'Auria

Received: 3 May 2021

Accepted: 16 June 2021

Published: 19 June 2021

Publisher's Note: MDPI stays neutral with regard to jurisdictional claims in published maps and institutional affiliations.

Copyright: (c) 2021 by the authors. Licensee MDPI, Basel, Switzerland. This article is an open access article distributed under the terms and conditions of the Creative Commons Attribution (CC BY) license (https:// creativecommons.org/licenses/by/ $4.0 /)$.
Department of Pharmaceutical Botany, Medical University of Lublin, Chodźki 1 Str., 20-093 Lublin, Poland; renata.nowak@umlub.pl

* Correspondence: wioleta.pietrzak@umlub.pl

\begin{abstract}
The content of plant secondary metabolites is not stable, and factors such as the region/location effect and seasonal variations have an impact on their chemical composition, especially in parasitic plants. Research in this area is an important step in the development of quality parameter standards of medicinal plants and their finished products. The effects of the time and place of harvest and the host tree species on the chemical composition and antioxidant activity of mistletoe extracts were investigated. Statistical tools were used to evaluate the results of the spectrophotometric and LC-ESI-MS/MS studies of the phenolic composition and antioxidant activity. The investigations indicate that the qualitative and quantitative composition, influencing the biological activity of mistletoe extracts, largely depends on the origin of the plant. The mistletoe extracts exhibited a rich phenol profile and high antioxidant activity. The chemometric analysis indicated that mistletoe collected from conifers (Viscum abietis and Viscum austriacum) had the most advantageous chemical composition and antioxidant activity. Moreover, the chemical profile and biological activity of the plant material were closely related to the climatic conditions and location of the harvested plant. Higher levels of phenolic compounds and high antioxidant activity were found in extracts obtained from plant material collected in cold weather with the presence of snow and less sunshine (autumn-winter period).
\end{abstract}

Keywords: Viscum album; LC-MS analysis; polyphenols; antioxidant activity

\section{Introduction}

Viscum album L. (Loranthaceae), commonly known as mistletoe, is an evergreen hemiparasitic plant widely distributed throughout the globe. This amazing plant lives at the expense of its hosts, i.e., various tree species. Chemical and pharmacological studies of mistletoe have identified different kinds of constituents such as viscotoxins, phenylpropanes, lignans, flavonoids, amines, polysaccharides, and lectins (ML1, ML2, ML3, and ML4) [1]. Some of them, especially flavonoids and phenolic acids, are natural antioxidants involved in the biological activity of the plant. The biological activity of Viscum, such as antioxidant, anti-inflammatory, and antibacterial properties as well as antiepileptic, immunostimulatory, and antiviral activity, have been reported [2-7]. One of the most important uses of mistletoe extracts is cancer therapy, including breast cancer [3,8], pancreatic cancer [9], bladder cancer [10], laryngeal cancer [11], lymphoblastic leukemia [12], and on medulloblastoma cells [13]. Water extracts from fresh mistletoe exert their anticancer effects by multifarious ways-immune augmentation, tumor prevention, malignant tissue inhibition, the moderation of chemotherapeutics side effects and DNA protection. The most active ingredients of these extracts are lectins and viscotoxins, whose content are not stable. Research in this area indicates species variability and seasonal fluctuations of the composition of mistletoe. The mistletoe-based formulations such as Iscador, Isorel, 
Iscucin, Lektinol, Eurixor, Helixor, Abnoba-viscum and recombinant lectin ML-1 have been approved for commercial use [14,15].

The recent literature also provides reports on the hypoglycemic effect of mistletoe preparations [6,16-18]. However, due to the diversity of products from mistletoe, which is a parasitic plant, and the proportions of pharmacologically relevant constituents, the interpretation of clinical research is difficult.

The results of many studies on the content of phenolic metabolites in medicinal plants have confirmed the hypothesis that these compounds significantly contribute to the antioxidant activity. The literature reports beneficial effects of antioxidants in the chemoprevention of various diseases caused by/or related to oxidative stress induced by excess free radicals in the human body. These diseases include cancer, hypertension, heart disease, and diabetes [19]. In particular, the use of antioxidants in the treatment of diabetes is extremely important. Oxidative stress contributes to the loss of $\beta$-cell function, the aggravation of insulin resistance, and the development of vascular complications. In patients with diabetes, the level of oxidative damage increases with the severity of the disease [20].

The content of secondary plant metabolites is not stable. Studies have shown that the content of phenolic compounds may vary depending on biotic and abiotic factors, the growth stage, the part of the plant, and the characteristics of the environment [21-23]. Most herbal medicines produced currently in a majority of developing countries lack proper quality specification and standards. The quality of the finished product is based on the quality of raw materials, which also depends on various genetic, ontogenic, morphogenetic, and environmental factors. These factors influence the biosynthesis of secondary plant metabolites and fluctuation in their contents. These facts should be taken into account while developing quality parameter standards of medicinal plants and their finished products $[24,25]$. Especially in the case of parasitic plants, factors such as the region/location effect and seasonal variation have an impact on the chemical composition of the plant.

Mistletoes are leafless flowering parasitic plants that kill by slowly robbing the tree of food and water. Their infections can retard growth and reduce seed production and wood quality. Heavy, long-term infections can kill trees. Although mistletoe infections are a common problem in many countries, the plant has a rich chemical composition. Mistletoe can biosynthesize its own compounds or can take some nutrients from the host trees. It has been suggested that the phytochemical profile of Viscum depends on the host of this parasitic plant [26-30]. The chemical composition and biological activity of mistletoe is not stable and may be associated with environmental conditions, such as temperature, carbon dioxide concentration, pollution, soil fertility, and season of the year [31].

The aim of the present study was to investigate the effect of the time and place of harvest and the host tree species on the chemical composition and antioxidant activity of mistletoe extracts. Moreover, in the current work, chemometric analysis of the results of the spectrophotometric and LC-ESI-MS/MS studies and climatic conditions was performed. It should be emphasized that this study is the first of such a comprehensive analysis of the impact of climatic factors, place of harvest, and host tree on the quality of harvested Viscum herb.

\section{Results and Discussion}

Mistletoe is a chemical-rich plant. Studies carried out so far have shown the presence of a wide variety of compounds responsible for the properties and biological activity of the genus Viscum L. Phenolics and flavonoids present in mistletoe are largely responsible for its biological effects, including anti-radical activity. Therefore, it is important to develop a method for the acquisition of extracts with a high content of biologically active compounds $[7,32,33]$. For a long time, scientists have been interested in the issue of the impact of the host on the chemical composition in mistletoe. Previous studies in this area are often contradictory and ambiguous in this regard, suggesting that the species of tree parasitized by mistletoe may partially determine the specific synthesis of some secondary 
metabolites [26-30]. The variability of the chemical composition and biological activity of mistletoe can also be associated with environmental conditions, i.e., ambient temperature, carbon dioxide concentration, pollution, soil fertility, and season [31].

\subsection{Effect of the Harvest Season on the Chemical Composition and Antioxidant Activity of Mistletoe Extracts (Viscum album subsp. album)}

In this part of the study, changes in the composition of polyphenols and flavonoids and antioxidant activity depending on the time of mistletoe harvest were examined.

The impact of the mistletoe collection period on the chemical composition and biological activity of extracts was studied previously by Vicas et al. (2011) and Önay-Uçar et al. (2006). The authors studied the TPC and antioxidant activity of aqueous and methanolic extracts from leaves and stems of mistletoe in three periods (May, July, and December) [33] and the antioxidant activity of methanolic extracts from Viscum album leaves harvested in February and July [7]. They found that the differences in the antioxidant activity of mistletoe harvested from different trees and in different seasons can be attributed to factors such as climate and temperature, which can significantly affect the chemical composition and antioxidant activity of plants [7,33]. However, the authors did not refer their results to climatic conditions (e.g., temperature) and places of harvesting the plant material for testing; hence, the data in this area are insufficient.

Therefore, preliminary screening research was performed to determine the effect of climatic factors and raw material harvest time on the chemical composition and antioxidant activity of mistletoe extracts. To the best of our knowledge, no such thorough research in this topic has been conducted.

In this study, plant material was collected from the same host tree species (Populus nigra L.) and from the same harvesting place (Olszowiec), i.e., factors that could affect the results were eliminated.

The results of total phenolic content (TPC), flavonoid content (TFC), and $\mathrm{EC}_{50}$ values of extracts from mistletoe harvested at different times from Populus nigra L. are shown in Figure 1.

The TPC value varied between 7.146 and $9.345 \mathrm{mg} \mathrm{GA} \mathrm{g}^{-1}$ of dry extract, TFC—from 1.888 to $2.888 \mathrm{mg} \mathrm{Q} \mathrm{g}^{-1}$ of dry extract, and $\mathrm{EC}_{50}$ values from 13.051 to $21.361 \mathrm{mg}$ dry extract $\mathrm{mg}^{-1}$ of $\mathrm{DPPH}^{\bullet}$. The results obtained in the present study showed differences between the harvest seasons, with the highest amount of polyphenols and flavonoids and high antioxidant activity in extracts from mistletoe collected in the autumn-winter period (November-March).

The study included data on the meteorological conditions prevailing during the harvest time in the Olszowiec region, which are shown in Table 1. Moreover, statistical analysis of the results was performed and Spearman correlation coefficients were calculated (Table 2).

Based on the results of spectrophotometric analysis, it can be seen that the extracts from the plant material collected in February, March, and April 2017 contained more polyphenols and flavonoids and had higher antiradical activity than the samples obtained from mistletoe harvested in February, March, and April in 2016. As regards the meteorological conditions recorded during the harvest time in the Olszowiec region, it can be concluded that the improved properties of the extracts from 2017, compared to those from 2016, are related to:

- the lower average air temperature in February-April 2017;

- the presence, thickness, and deposition time of snow cover in February-April 2017;

- lower sunshine duration in February-April 2017.

Moreover, based on the results of the statistical analysis of the total phenolic and flavonoid content, $\mathrm{EC}_{50}$ values, and climatic conditions, it can be concluded that:

- there was a strong relationship between TPC, $\mathrm{EC}_{50}$, and the average air temperature. The correlation coefficients were 0.8355 and 0.7466 , respectively; 
- the total phenolic content and antioxidant activity largely depended on the maximum snow depth, maximum persistence of snow cover, and the number of days with snow. The correlation coefficients varied between 0.7178 and 0.8341 ;

- there was a low correlation between the values of TFC and climatic conditions prevailing during the harvest of the plant material.

Total phenolic content (TPC)
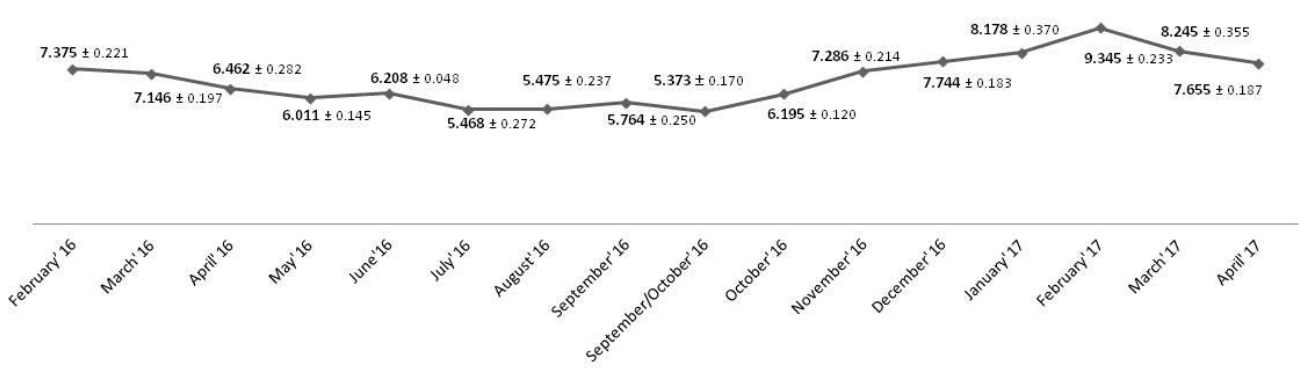

Total flavonoid content (TFC)

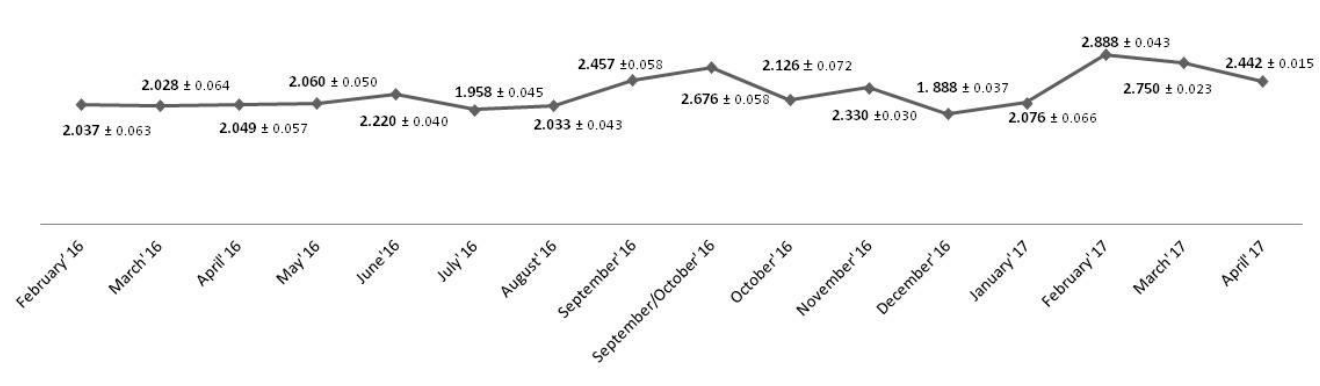

Antioxidant activity (EC50)

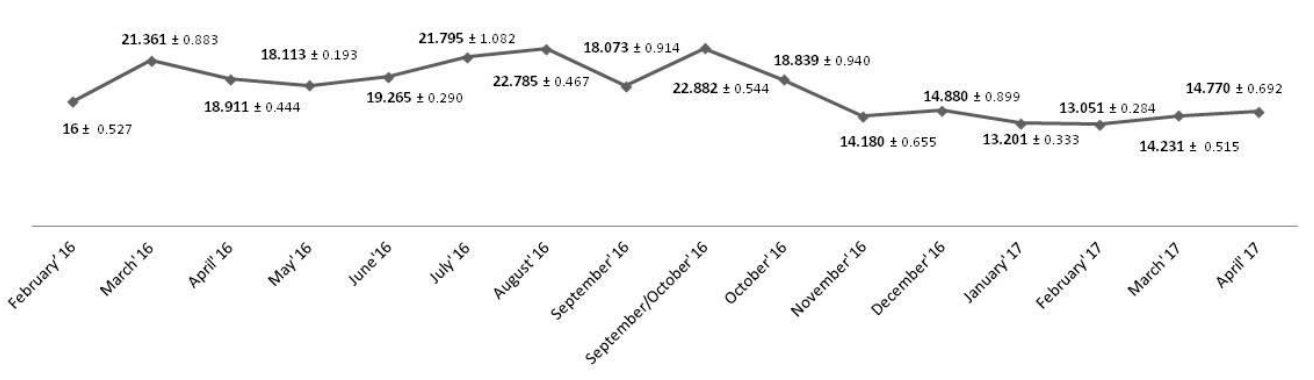

Figure 1. Total phenolic content (TPC; mg GA/g of dry extract), flavonoid content (TFC; mg Q/g of dry extract) and antioxidant activity $\left(\mathrm{EC}_{50} ; \mathrm{mg}\right.$ dry extract $/ \mathrm{mg}$ of $\left.\mathrm{DPPH}\right)$ of methanol extracts from mistletoe (from Populus nigra L.) harvested at various time in Olszowiec region.

Table 1. Meteorological conditions during harvest time in Olszowiec region based on climate monitoring bulletin Polish.

\begin{tabular}{|c|c|c|c|c|c|c|}
\hline Sample Name & $\begin{array}{l}\text { The Average Air } \\
\text { Temperature }\left(^{\circ}\right)\end{array}$ & $\begin{array}{l}\text { Max Snow } \\
\text { Depth (cm) }\end{array}$ & $\begin{array}{c}\text { Max Running Time } \\
\text { with Snow } \\
\text { Cover (days) }\end{array}$ & $\begin{array}{l}\text { The Number of } \\
\text { Days with } \\
\text { Snow (days) }\end{array}$ & $\begin{array}{c}\text { Monthly Total } \\
\text { Precipitation (mm) }\end{array}$ & $\begin{array}{c}\text { Sunshine } \\
\text { Duration (h) }\end{array}$ \\
\hline February'16 & -6.1 & 17 & 24 & 27 & 20 & $70-80$ \\
\hline March'16 & 5.9 & - & - & - & $30-40$ & $150-160$ \\
\hline April'16 & 9.3 & 2 & - & 1 & $30-40$ & $180-190$ \\
\hline May'16 & 15.1 & - & - & - & $30-40$ & $280-300$ \\
\hline June'16 & 16.8 & - & - & - & $80-90$ & $210-220$ \\
\hline July'16 & 20.3 & - & - & - & $50-60$ & $280-300$ \\
\hline August'16 & 18.7 & - & - & - & $50-60$ & $220-240$ \\
\hline
\end{tabular}


Table 1. Cont.

\begin{tabular}{|c|c|c|c|c|c|c|}
\hline Sample Name & $\begin{array}{l}\text { The Average Air } \\
\text { Temperature }\left({ }^{\circ}\right)\end{array}$ & $\begin{array}{l}\text { Max Snow } \\
\text { Depth }(\mathrm{cm})\end{array}$ & $\begin{array}{c}\text { Max Running Time } \\
\text { with Snow } \\
\text { Cover (days) }\end{array}$ & $\begin{array}{l}\text { The Number of } \\
\text { Days with } \\
\text { Snow (days) }\end{array}$ & $\begin{array}{c}\text { Monthly Total } \\
\text { Precipitation (mm) }\end{array}$ & $\begin{array}{c}\text { Sunshine } \\
\text { Duration (h) }\end{array}$ \\
\hline September'16 & 14.5 & - & - & - & $30-40$ & $170-180$ \\
\hline September/October'16 & 11.4 & - & - & - & $60-70$ & $150-160$ \\
\hline October'16 & 8.2 & - & - & - & $80-90$ & $120-130$ \\
\hline November'16 & 5.6 & - & - & - & $20-30$ & $30-40$ \\
\hline December'16 & -2.5 & 14 & 29 & 30 & $20-30$ & $20-30$ \\
\hline January'17 & -3.1 & 29 & 22 & 23 & $50-60$ & $20-30$ \\
\hline February'17 & -0.5 & 25 & 28 & 20 & $40-50$ & $0-20$ \\
\hline March'17 & -1.8 & 20 & 24 & 26 & $50-60$ & $110-120$ \\
\hline April'17 & 8.2 & 27 & 11 & 11 & $40-50$ & $150-160$ \\
\hline Winter 2016 & -1.3 & 17 & 42 & 53 & $100-125$ & $150-160$ \\
\hline Winter 2017 & -2 & 29 & 50 & 81 & $100-125$ & $70-80$ \\
\hline
\end{tabular}

Table 2. Spearman correlation coefficient values $(X, Y)$ for the tested parameters.

\begin{tabular}{cc}
\hline Test Parameter & $\mathbf{R}_{\text {Spearman }}(\mathbf{X}, \mathbf{Y})$ \\
\hline TPC and the average air temperature & -0.8355 \\
TPC and maximum snow depth & 0.8341 \\
TPC and maximum running time with snow cover & 0.8297 \\
TPC and the number of days with snow & 0.7698 \\
TFC and the average air temperature & -0.1631 \\
TFC and maximum snow depth & 0.3208 \\
TFC and maximum running time with snow cover & 0.2231 \\
TFC and the number of days with snow & 0.1251 \\
EC 50 and the average air temperature & 0.7466 \\
EC 50 and maximum snow depth & -0.7768 \\
EC $_{50}$ and maximum running time with snow cover & -0.7444 \\
EC 50 and the number of days with snow & -0.7178 \\
\hline
\end{tabular}

2.2. Analysis of the Phenolic Profile of Mistletoe Extracts Depending on the Place of Harvesting the Plant Raw Material

In this part of the study, the effect of the harvesting place on the similarity of the phenolic profile of mistletoe extracts harvested from apple trees (Malus domestica Borkh.) was examined. For this purpose, spectrophotometric screening tests (total phenolic content, total flavonoid content, and antioxidant activity measured with the DPPH ${ }^{\bullet}$ method) and LC-MS identification of phenolic acids (LC-ESI-MS/MS) in the mistletoe extracts were carried out (Tables 3 and 4).

Table 3. Phenolic acid contents ( $\mu$ g per g of dry extract) in extracts from mistletoe collected from Malus domestica Borkh. $( \pm \mathrm{SD}, n=9)$.

\begin{tabular}{|c|c|c|c|c|c|}
\hline \multirow{2}{*}{ Compound } & \multicolumn{5}{|c|}{ Viscum album subsp. album (from Malus domestica Borkh.) } \\
\hline & T1 & T2 & T3 & $\mathrm{T} 4$ & T5 \\
\hline Gallic acid & $-b$ & $-\mathrm{b}$ & $-b$ & $-\mathrm{b}$ & $-\mathrm{b}$ \\
\hline Protocatechuic acid & $70.71 \pm 0.57$ & $114.10 \pm 2.62$ & $64.60 \pm 0.039$ & $107.31 \pm 5.37$ & $233.44 \pm 10.27$ \\
\hline Gentisic acid & - b & - b & - b & $-\mathrm{b}$ & $-b$ \\
\hline 4-hydroxybenzoic acid & trace $^{a}$ & trace $^{a}$ & trace $^{\mathrm{a}}$ & $27.39 \pm 1.10$ & $8.85 \pm 0.10$ \\
\hline Vanilic acid & trace $^{a}$ & trace $^{a}$ & trace $^{a}$ & trace $^{a}$ & trace $^{a}$ \\
\hline Caffeic acid & $30.10 \pm 0.39$ & $21.4 \pm 0.13$ & $48.32 \pm 0.19$ & $57.91 \pm 1.33$ & $50.65 \pm 0.25$ \\
\hline Syringic acid & $46.06 \pm 2.07$ & $56.23 \pm 0.56$ & $52.87 \pm 0.85$ & $72.95 \pm 1.31$ & $51.55 \pm 0.10$ \\
\hline$p$-Coumaric acid & $15.05 \pm 0.33$ & $11.41 \pm 0.40$ & $16.68 \pm 0.30$ & $16.60 \pm 0.65$ & $15.05 \pm 0.38$ \\
\hline Ferulic acid & $5.59 \pm 0.28$ & $7.71 \pm 0.11$ & $10.88 \pm 0.30$ & $13.49 \pm 0.26$ & $10.09 \pm 0.24$ \\
\hline Salicylic acid & trace $^{a}$ & trace $^{a}$ & $0.72 \pm 0.01$ & $2.79 \pm 0.01$ & $0.81 \pm 0.04$ \\
\hline
\end{tabular}


Table 3. Cont.

\begin{tabular}{|c|c|c|c|c|c|}
\hline \multirow{2}{*}{ Compound } & \multicolumn{5}{|c|}{ Viscum album subsp. album (from Malus domestica Borkh.) } \\
\hline & T1 & T2 & T3 & T4 & T5 \\
\hline Veratric acid & $-\mathrm{b}$ & $-\mathrm{b}$ & $-\mathrm{b}$ & $-\mathrm{b}$ & $-\mathrm{b}$ \\
\hline Synapic acid & $28.14 \pm 0.06$ & $30.24 \pm 0.42$ & $24.40 \pm 1.12$ & $68.87 \pm 1.38$ & $15.05 \pm 0.20$ \\
\hline$m$-Coumaric acid & $-\mathrm{b}$ & $-\mathrm{b}$ & $-\mathrm{b}$ & $-\mathrm{b}$ & $-\mathrm{b}$ \\
\hline Rosmarinic acid & trace $^{\mathrm{a}}$ & trace $^{a}$ & trace $^{a}$ & trace $^{a}$ & trace $^{a}$ \\
\hline TOTAL & 195.65 & 241.09 & 218.47 & 367.31 & 385.49 \\
\hline
\end{tabular}

Table 4. Total phenolic content (TPC; mg GA per g of dry extract), flavonoid content (TFC; mg Q per g of dry extract) and antioxidant activity (EC50; $\mathrm{mg}$ dry extract per $\mathrm{mg}$ of $\mathrm{DPPH}^{\bullet}$ ) of extracts from mistletoe collected from Malus domestica Borkh.

\begin{tabular}{ccccccc}
\hline & \multicolumn{5}{c}{ Viscum album subsp. album (from Malus domestica Borkh.) } \\
\cline { 2 - 6 } & T1 & T2 & T3 & T4 & T5 \\
\hline TPC & $34.800 \pm 0.728$ & $48.628 \pm 1.316$ & $36.655 \pm 1.666$ & $37.216 \pm 0.190$ & $33.789 \pm 1.606$ \\
TFC & $13.786 \pm 0.257$ & $12.662 \pm 0.092$ & $11.722 \pm 0.235$ & $13.571 \pm 0.155$ & $12.977 \pm 0.026$ \\
EC 50 & $4.608 \pm 0.190$ & $3.824 \pm 0.073$ & $3.753 \pm 0.094$ & $3.92 \pm 0.086$ & $4.136 \pm 0.095$ \\
\hline
\end{tabular}

The spectrophotometric studies showed slight differences in the total content of phenolics (from $33.789 \mathrm{mg} \mathrm{GA}$ per g of dry extract for sample T5 to $48.628 \mathrm{mg} \mathrm{GA} \mathrm{g}^{-1}$ of dry extract for sample T2), the content of flavonoids (from $11.722 \mathrm{mg} \mathrm{Q} \mathrm{g}^{-1}$ of dry extract for sample $\mathrm{T} 3$ to $13.786 \mathrm{mg} \mathrm{Q} \mathrm{g}^{-1}$ of dry extract for sample T1), and antioxidant activity (from $3.753 \mathrm{mg}$ dry extract per $\mathrm{mg}$ of $\mathrm{DPPH}^{\bullet}$ for sample T3 to $4.608 \mathrm{mg}$ dry extract per $\mathrm{mg}$ of $\mathrm{DPPH}^{\bullet}$ for sample T1).

However, more diverse results were observed in the spectrometric studies of phenolic acids. The higher differences in the content of acids in extracts from the mistletoe harvested from apple trees were observed in the case of protocatechuic (from $64.60 \mu \mathrm{g}$ per g of dry extract for sample T3 to $233.44 \mu \mathrm{g}$ per g of dry extract for sample T5), syringic (from $21.40 \mu \mathrm{g}$ per $\mathrm{g}$ of dry extract for sample $\mathrm{T} 2$ to $57.91 \mu \mathrm{g}$ per $\mathrm{g}$ of dry extract for sample T4), caffeic (from $46.06 \mu \mathrm{g}$ per $\mathrm{g}$ of dry extract for sample T1 to $72.95 \mu \mathrm{g}$ per g of dry extract for sample T4), and synapinic (from $15.05 \mu \mathrm{g}$ per g of dry extract for sample T5 to $68,87 \mu \mathrm{g}$ per $\mathrm{g}$ of dry extract for sample T4) acids.

The quantitative results of phenolic acids in mistletoe extracts collected from five different apple trees (from five different areas of the Lublin region-Supplementary Table S1) and the spectrophotometric results were subjected to chemometric analysis. The calculations were performed in Statistica version 10.0.

Compliance with the normal distribution of individual parameters was determined using the Shapiro-Wilk test. The data were subsequently standardized and cluster analysis was performed for the data. For this purpose, one method of cluster analysis was applied: k-means clustering. In general, a k-means algorithm groups methods in clusters of the greatest possible distinction. The results of the statistical analysis are shown in Supplementary Figure S1.

In this part of the research, the host tree species (Malus domestica Borkh.) and the mistletoe harvesting time (November 2017) were the same for each of the tested T1-T5 extracts (each extract was an average sample of 10 apple trees from one orchard); therefore, this study eliminated the impact of these factors on the chemical composition of mistletoe. It can be assumed that the qualitative and quantitative chemical composition of extracts is affected by the place of harvesting of the plant raw material, which is confirmed by previous theoretical literature reports. To the best of our knowledge, there is no experimental research on the impact of the raw material harvesting site on the chemical composition in 
mistletoe. Our tests are preliminary screening experimental research in this field, and for further and deeper analysis is necessary.

In summary, based on the spectrophotometric screening tests, it can be seen that the extracts obtained from mistletoe parasitizing Malus Mill. (T1-T5) did not show significant differences in the TPC, TFC, and $\mathrm{EC}_{50}$ values, as they originated from the same host species-Malus domestica Borkh.

In addition, the statistical analysis shows that the place of harvesting of plant material is an additional factor that can affect the diversity of the chemical composition of extracts determined with the LC-MS method.

\subsection{Analysis of the Phenolic Profile of Mistletoe Extracts Depending on the Host Tree Species}

As mentioned previously, the chemical composition and antioxidant activity of mistletoe extracts are not stable and depend on various factors. In the case of hemi-parasitic plants, this problem should be considered in the context of their habitats, i.e., the influence of the host trees on the chemical composition of the plant.

Therefore, after assessing the impact of climatic conditions and the time and place of harvesting of the plant material, we decided to determine the possible relationships between the chemical composition and antioxidant activity of mistletoe and the host tree species from which the plant was harvested.

Comparative spectrophotometric studies of methanolic extracts from mistletoe were performed to determine the content of phenolic compounds (TPC, TFC) and antioxidant activity. The results are presented in Table 5 .

Table 5. Total phenolic content (TPC), flavonoid content (TFC), antioxidant activity (DPPH• scavenging assay, antiradical capacity determination with $\mathrm{ABTS}^{+} \bullet$, Oxygen Radical Absorbance Capacity (ORAC) assay) and efficiency of extraction (EE) ( $\mathrm{g}$ of dry extract obtained from $1 \mathrm{~g}$ raw material) in different mistletoe extracts. Values are presented in mean \pm standard deviation $(n=9)$ and evaluated by one-way ANOVA test (post test: Duncan test). Different superscript letters $\left({ }^{a-g}\right)$ in the same rows denotes significant differences at $p<0.05$.

\begin{tabular}{|c|c|c|c|c|c|c|}
\hline \multirow[b]{2}{*}{ Samples } & \multirow[b]{2}{*}{$\begin{array}{l}\mathrm{EE} \\
(\%)\end{array}$} & \multirow[b]{2}{*}{$\begin{array}{c}\text { TPC } \\
\text { (mg GA/g } \\
\text { Dry Extract) }\end{array}$} & \multirow[b]{2}{*}{$\begin{array}{c}\text { TFC } \\
\text { (mg Q/g } \\
\text { Dry Extract) }\end{array}$} & \multicolumn{3}{|c|}{ Antioxidant Acticity } \\
\hline & & & & $\begin{array}{c}\mathrm{EC}_{50} \\
(\mathrm{mg} \text { Dry } \\
\text { Extract/mg DPPH•) }\end{array}$ & $\begin{array}{c}\text { TEAC } \\
\text { (mM Trolox } / g \\
\text { Dry Extract) }\end{array}$ & $\begin{array}{c}\text { ORAC } \\
\text { (mM Trolox/g } \\
\text { Dry Extract) }\end{array}$ \\
\hline \multicolumn{7}{|c|}{ Viscum album subsp. album } \\
\hline Malus domestica Borkh & 0.172 & $38.22^{a} \pm 0.73$ & $12.94^{\text {adef }} \pm 0.26$ & $4.05^{\mathrm{abc}} \pm 0.19$ & $0.09^{\mathrm{a}} \pm 0.02$ & $1.54^{\mathrm{a}} \pm 0.05$ \\
\hline Populus nigra L. & 0.181 & $38.53^{\mathrm{a}} \pm 0.23$ & $16.36^{\mathrm{bc}} \pm 0.41$ & $2.37^{a b} \pm 0.09$ & $0.18^{b} \pm 0.04$ & $1.96^{\mathrm{b}} \pm 0.09$ \\
\hline Populus nigra L. 'Italica' & 0.169 & $38.09^{\mathrm{a}} \pm 0.96$ & $16.04^{\mathrm{bcf}} \pm 0.28$ & $2.88^{a b} \pm 0.08$ & $0.15^{b} \pm 0.01$ & $1.78^{\mathrm{a}} \pm 0.02$ \\
\hline Crataegus monogyna Jacq. & 0.158 & $38.05^{\mathrm{a}} \pm 1.07$ & $12.09^{\text {ad }} \pm 0.51$ & $2.92^{\mathrm{ab}} \pm 0.12$ & $0.17^{\mathrm{b}} \pm 0.01$ & $1.88^{\mathrm{b}} \pm 0.05$ \\
\hline Sorbus aucuparia L. & 0.139 & $38.73^{\mathrm{a}} \pm 0.26$ & $12.86^{\text {ade }} \pm 0.21$ & $4.35^{\mathrm{a}} \pm 0.08$ & $0.07^{\mathrm{a}} \pm 0.03$ & $1.41^{\mathrm{a}} \pm 0.09$ \\
\hline $\begin{array}{c}\text { Fraxinus pensylvanica } \\
\text { Marsh. }\end{array}$ & 0.170 & $31.49^{b} \pm 0.86$ & $14.19^{\text {aef }} \pm 0.09$ & $2.99^{a b} \pm 0.07$ & $0.15^{b} \pm 0.02$ & $1.91^{\mathrm{b}} \pm 0.03$ \\
\hline Fraxinus exscelsior L. & 0.168 & $30.56^{\mathrm{bc}} \pm 1.76$ & $14.56^{\text {acef }} \pm 0.35$ & $4.21^{\mathrm{ab}} \pm 0.11$ & $0.08^{\mathrm{a}} \pm 0.02$ & $1.25^{\mathrm{a}} \pm 0.06$ \\
\hline Acer platanoides L. & 0.143 & $33.49^{\mathrm{d}} \pm 0.09$ & $13.14^{\text {adef }} \pm 0.47$ & $2.78^{a b} \pm 0.15$ & $0.14^{\mathrm{b}} \pm 0.01$ & $1.92^{b} \pm 0.07$ \\
\hline Acer saccharinum L. & 0.158 & $32.33^{\mathrm{bcd}} \pm 0.07$ & $13.21^{\text {adef }} \pm 0.52$ & $2.14^{\mathrm{ab}} \pm 0.09$ & $0.19^{\mathrm{b}} \pm 0.03$ & $2.02^{b} \pm 0.08$ \\
\hline Tilia cordata Mill. & 0.166 & $34.91^{\mathrm{d}} \pm 0.23$ & $11.89^{\mathrm{ad}} \pm 0.24$ & $2.79^{\mathrm{ab}} \pm 0.12$ & $0.12^{b} \pm 0.02$ & $1.84^{b} \pm 0.09$ \\
\hline \multicolumn{7}{|c|}{ V. album subsp. abietis } \\
\hline Abies alba Mill. & 0.164 & $56.75^{\mathrm{e}} \pm 1.31$ & $10.11^{\mathrm{g}} \pm 0.42$ & $2.57^{\mathrm{ab}} \pm 0.10$ & $0.21^{\mathrm{b}} \pm 0.08$ & $1.95^{\mathrm{b}} \pm 0.10$ \\
\hline \multicolumn{7}{|c|}{ V. album subsp. austriacum } \\
\hline Pinus sylvestris L. & 0.190 & $39.11^{\mathrm{a}} \pm 1.21$ & $16.90^{b c} \pm 0.32$ & $2.56^{\mathrm{ab}} \pm 0.11$ & $0.19 \pm 0.07$ & $2.01 \pm 0.10$ \\
\hline
\end{tabular}

The results show that the total phenolic content ranged from $30.56 \pm 1.76 \mathrm{mg} \mathrm{GA} \mathrm{g}^{-1}$ of dry extract for mistletoe extract from Fraxinus exscelsior L. (Viscum album subsp. album) to $56.75 \pm 1.31 \mathrm{mg}$ GA per $\mathrm{g}$ of dry extract for mistletoe extract from Abies alba Mill. (Viscum album subsp. abietis). TFC varied from $10.11 \pm 0.42 \mathrm{mg} \mathrm{Q} \mathrm{g}^{-1}$ of dry extract (for mistletoe extract from Abies alba Mill.) to $16.90 \pm 0.32 \mathrm{mg} \mathrm{Q} \mathrm{g}^{-1}$ of dry extract (for mistletoe extract from Pinus sylvestris L. $-V$. austriacum). 
The antioxidant activity was measured using the DPPH${ }^{\bullet}$ scavenging assay, antiradical capacity determination with $\mathrm{ABTS}^{+\bullet}$, and the Oxygen Radical Absorbance Capacity (ORAC) assay.

The lowest $\mathrm{EC}_{50}$ value, i.e., the highest antioxidant activity determined with the $\mathrm{DPPH}^{\bullet}$ method, was observed in the mistletoe extract obtained from Acer saccharinum $\mathrm{L}$. $\left(2.14 \pm 0.09 \mathrm{mg}\right.$ dry extract $\mathrm{mg}^{-1}$ of $\left.\mathrm{DPPH}^{\bullet}\right)$. The mistletoe extracts from Malus domestica Borkh., Fraxinus exscelsior L., and Sorbus aucuparia L. had the lowest antioxidant activity $\left(\mathrm{EC}_{50}\right.$ of $4.05 \pm 0.19,4.21 \pm 0.11$, and $4.35 \pm 0.08 \mathrm{mg}$ dry extract per $\mathrm{mg}$ of $\mathrm{DPPH}^{\bullet}$, respectively).

In the $\mathrm{ABTS}^{+\bullet}$ method, the highest antioxidant activity was exhibited by the extract from mistletoe harvested from Abies alba Mill. ( $0.21 \pm 0.08 \mathrm{mM}$ Trolox per $\mathrm{g}$ dry extract).

In the ORAC method, the extracts from mistletoe collected from conifers (Viscum album subsp. abietis and Viscum album subsp. austriacum) were the most active samples $(1.95 \pm 0.10$ and $2.01 \pm 0.10 \mathrm{mM}$ Trolox per $\mathrm{g}$ dry extract, respectively).

In order to show differences and similarities in the qualitative and quantitative chemical composition of mistletoe extracts from various host trees, the simple, rapid, reliable, and effective LC-ESI-MS/MS method was used. As shown by the available literature data, the quantitative and qualitative determinations of 14 phenolic acids and 16 flavonoid aglycones in three mistletoe subspecies collected from 12 host trees were performed for the first time (Tables 6 and 7). The chromatograms of phenolic acids and flavonoid aglycones for exemplary samples are shown in the Supplementary Materials in Figures S2 and S3.

As indicated by the results of the quantitative and qualitative studies of free phenolic acids in the methanolic extracts from Viscum album L., no veratric acid and 3-OH-cinnamic acid were found in the analyzed extracts. Rosmarinic and gentisic acids were detected only in trace amounts, depending on the sample tested. Gallic acid was present in small amounts in the tested samples from the raw material collected from Fraxinus exscelsior $\mathrm{L}$. (46.62 $\mu \mathrm{g} / \mathrm{g}$ dry extract) and Tilia cordata Mill. (33.71 $\mu \mathrm{g} / \mathrm{g}$ extract).

Protocatechuic acid was mainly present in the mistletoe extract collected from Malus domestica Borkh. (118.03 $\pm 0.86 \mu \mathrm{g} / \mathrm{g}$ extract), Fraxinus pensylvanica Marsh. (133.27 $\pm 1.20 \mu \mathrm{g} / \mathrm{g}$ extract), Fraxinus exscelsior L. (203.48 $\pm 9.16 \mu \mathrm{g} / \mathrm{g}$ of extract), Tilia cordata Mill. (138.17 $\pm 1.17 \mu \mathrm{g} / \mathrm{g}$ extract), and Abies alba Mill (114.29 $\pm 1.05 \mu \mathrm{g} / \mathrm{g}$ extract).

Vanillic acid was detected in all tested extracts in various amounts: from trace to large amounts for the mistletoe extracts from Populus nigra L. and Populus nigra L. 'Italica' and conifer mistletoe (V. album subsp. abietis and V. album subsp. austriacum).

4-hydroxybenzoic acid, which was most abundant in $V$. album subsp. abietis (164.91 $\pm 4.95 \mu \mathrm{g} / \mathrm{g}$ of extract), was a characteristic phenolic acid as well.

In the case of $p$-coumaric and syringic acids, the highest content was found in Populus nigra L. 'Italica' and conifer mistletoe (V. album subsp. abietis and V. album subsp. austriacum). In turn, salicylic acid was a characteristic compound for V. album subsp. austriacum and mistletoe extracts from Populus nigra L. and Populus nigra L. 'Italica'.

The analysis of the content of aglycones in the tested samples revealed the absence of compounds such as morin, chrysin, and prunetine, while taxifolin was present only in some samples in trace amounts.

Myricetin was found in the highest amounts in the mistletoe extract from Malus domestica Borkh. $(1.91 \pm 0.006 \mu \mathrm{g} / \mathrm{g}$ of extract). Eriodictiol significantly predominated in $V$. album subsp. album from Tilia cordata Mill., Fraxinus pensylvanica Marsh., and Fraxinus exscelsior L. Quercetin was determined only in V. album subsp. austriacum and V. album subsp. album from Malus domestica Borkh., whereas kaempferol was detected in V. austriacum and V. album from Acer platanoides L.

Extracts from $V$. austriacum also contained large amounts of sakuranetin, i.e., $14.44 \pm 0.14 \mu \mathrm{g} / \mathrm{g}$ of extract, and extracts from $V$. album harvested from Acer platanoides L. had large amounts of apigenin $(57.32 \pm 0.15 \mu \mathrm{g} / \mathrm{g}$ of extract). 
Table 6. Phenolic acids and flavonoid aglycones contents ( $\mu \mathrm{g} / \mathrm{g}$ dry extract) in extracts from Viscum album subsp. album collected from different host trees (average, $n=9$ ).

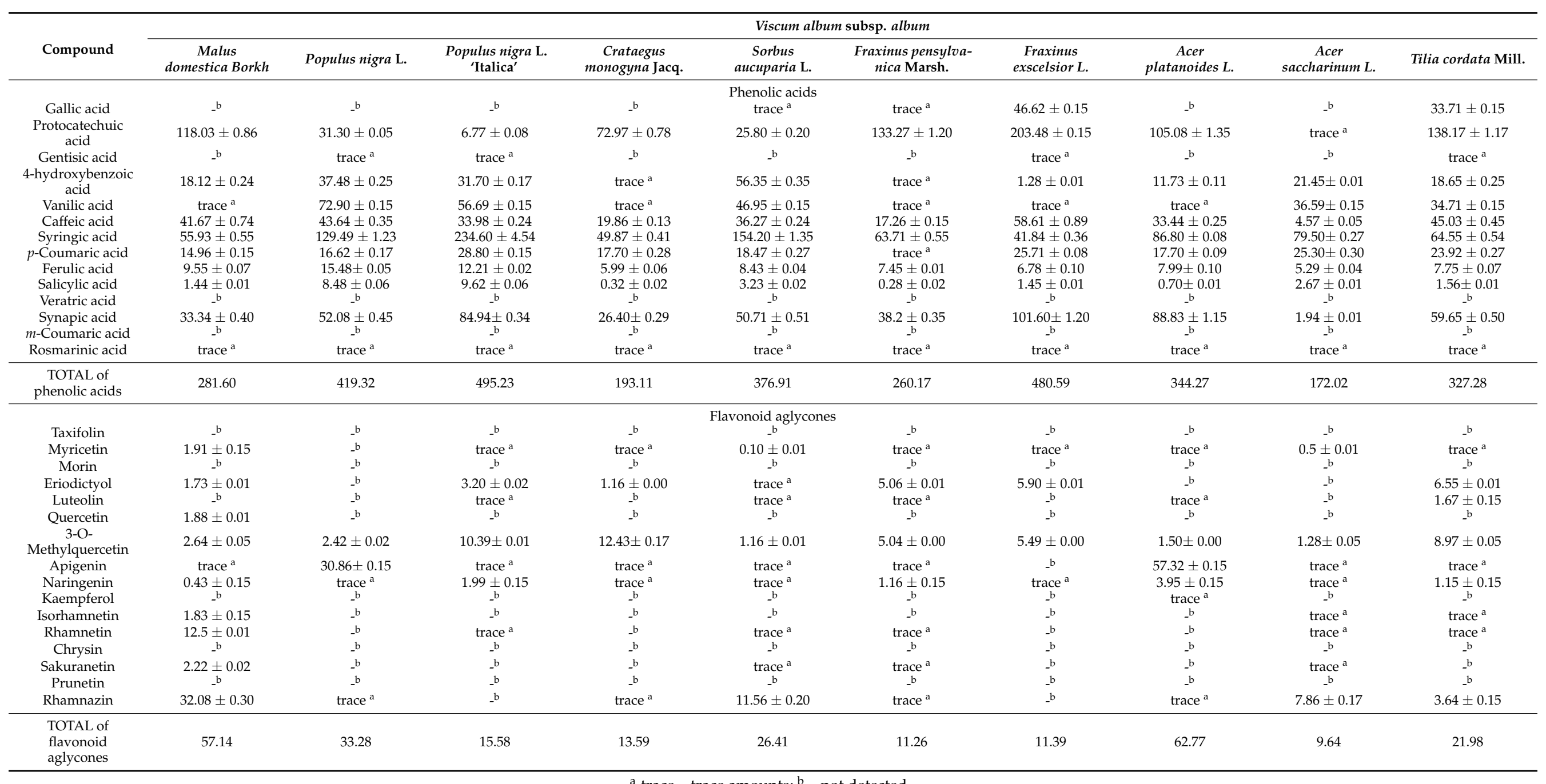

a trace-trace amounts; ${ }^{\mathrm{b}}$-not detected. 
Table 7. Phenolic acids and flavonoid aglycones contents ( $\mu \mathrm{g} / \mathrm{g}$ dry extract) in extracts from Viscum album subsp. abietis and austriacum (average, $n=9$ ).

\begin{tabular}{|c|c|c|}
\hline \multirow{2}{*}{ Compound } & V. album subsp. abietis & V. album subsp. austriacum \\
\hline & Abies alba Mill. & Pinus sylvestris L. \\
\hline \multicolumn{3}{|c|}{ Phenolic acids } \\
\hline Gallic acid & $-\mathrm{b}$ & $-\mathrm{b}$ \\
\hline Protocatechuic acid & $114.29 \pm 1.05$ & $17.90 \pm 0.20$ \\
\hline Gentisic acid & trace $^{a}$ & trace $^{a}$ \\
\hline 4-hydroxybenzoic acid & $164.91 \pm 4.95$ & $23.14 \pm 0.25$ \\
\hline Vanilic acid & $95.04 \pm 0.15$ & $81.24 \pm 0.15$ \\
\hline Caffeic acid & $48.82 \pm 0.47$ & $53.71 \pm 0.56$ \\
\hline Syringic acid & $163.91 \pm 1.47$ & $167.62 \pm 1.62$ \\
\hline$p$-Coumaric acid & $44.11 \pm 0.17$ & $42.76 \pm 0.41$ \\
\hline Ferulic acid & $5.31 \pm 0.04$ & $9.81 \pm 0.08$ \\
\hline Salicylic acid & $1.88 \pm 0.02$ & $5.24 \pm 0.04$ \\
\hline Veratric acid & $-\mathrm{b}$ & - b \\
\hline Synapic acid & $17.31 \pm 0.07$ & $11.68 \pm 0.11$ \\
\hline$m$-Coumaric acid & $-\mathrm{b}$ & - \\
\hline Rosmarinic acid & trace $^{a}$ & trace $^{a}$ \\
\hline TOTAL of phenolic acids & 601.45 & 403.29 \\
\hline \multicolumn{3}{|c|}{ Flavonoid aglycones } \\
\hline Taxifolin & $-b$ & $-b$ \\
\hline Myricetin & trace $^{a}$ & $0.12 \pm 0.00$ \\
\hline Morin & b & - b \\
\hline Eriodictyol & $-\mathrm{b}$ & $0.15 \pm 0.00$ \\
\hline Luteolin & -b & $-b$ \\
\hline Quercetin & $-\mathrm{b}$ & $0.21 \pm 0.02$ \\
\hline 3-O-Methylquercetin & $0.11 \pm 0.02$ & $1.41 \pm 0.01$ \\
\hline Apigenin & $0.43 \pm 0.02$ & trace $^{a}$ \\
\hline Naringenin & $1.75 \pm 0.01$ & $1.41 \pm 0.00$ \\
\hline Kaempferol & $-b$ & $1.07 \pm 0.01$ \\
\hline Isorhamnetin & -b & $2.44 \pm 0.01$ \\
\hline Rhamnetin & -b & $3.71 \pm 0.02$ \\
\hline Chrysin & - b & $-b$ \\
\hline Sakuranetin & $-\mathrm{b}$ & $14.44 \pm 0.17$ \\
\hline Prunetin & $-\mathrm{b}$ & $-b$ \\
\hline Rhamnazin & -b & $31.12 \pm 0.10$ \\
\hline $\begin{array}{l}\text { TOTAL of flavonoid } \\
\text { aglycones }\end{array}$ & 2.29 & 56.08 \\
\hline
\end{tabular}

a trace- trace amounts; ${ }^{\mathrm{b}}$-not detected.

Isoramnetin, rhamnetin, and rhamnazine were the most characteristic compounds in the mistletoe from Viscum austriacum and Viscum album from Malus domestica Borkh.

The highest amount of phenolic acids was determined with the LC-MS method in Viscum album subsp. abietis ( $601.45 \mu \mathrm{g} / \mathrm{g}$ of extract), and the highest content of flavonoid aglycones were detected in Viscum album subsp. austriacum $(56.08 \mu \mathrm{g} / \mathrm{g}$ of extract) and Viscum album from Malus domestica Borkh. (57.14 $\mu \mathrm{g} / \mathrm{g}$ of extract).

The results of the spectrophotometric assays and LC-MS analysis of phenolic compounds in the methanolic extracts from Viscum collected from various host tree species were subjected to chemometric analysis. The calculations were performed in Statistica version 10.0. Chemometrics facilitates understanding of chemical information obtained and correlates quality parameters or biological properties with analytical data. In this part of the study, the joining (tree-clustering) method of cluster analysis was applied. In the tree clustering, the Ward's method was used for amalgamation, and the Euclidean distance was adopted as a measure of distance between the clusters. The results of the statistical analysis, i.e., the hierarchical tree dendrogram, are shown in Figure 2. The tree dendrogram 
shows clusters of objects according to the strength of their correlation. This correlation can be seen in the expression profiles of objects from the same cluster.

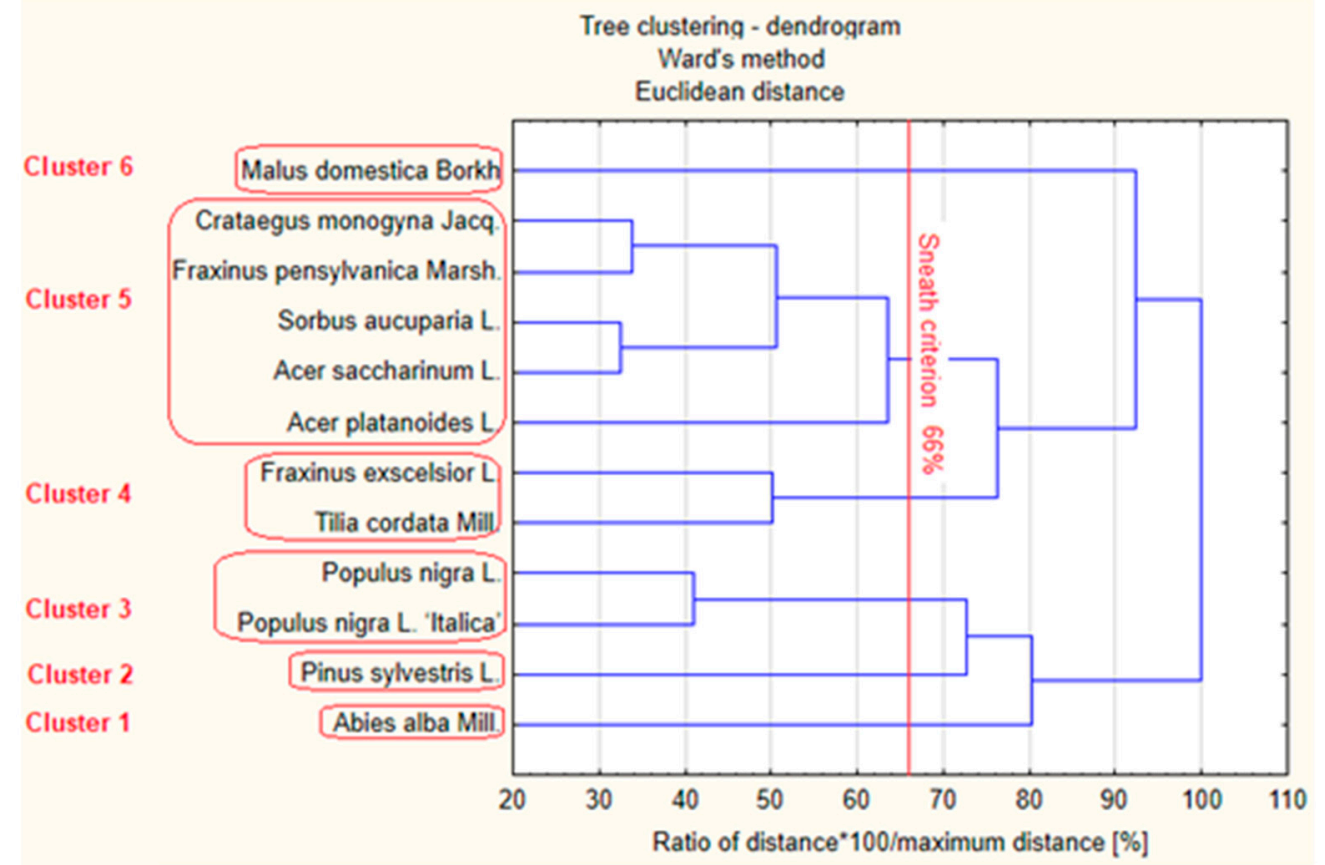

Figure 2. Dendrogram showing similarity of mistletoe extracts obtained from different host trees with a calibrated axis of the binding distance and with the $66 \%$ criterion of Sneath.

Based on the dendrogram, six groups showing relative similarity among the chemical composition in Viscum album L. can be identified according to the less restrictive Sneath's criterion (66\%). Figure 2 shows two separate clusters (cluster 1 and 2) with extracts of mistletoe harvested from conifers (Viscum abietis from Abies alba Mill. and Viscum austriacum from Pinus sylvestris L). A separate cluster 3 is also formed by extracts of mistletoe from poplar (V. album from Populus nigra L. and Populus nigra L. 'Italica'). Cluster 4 contains extracts of mistletoe from Fraxinus exscelsior L. and Tilia cordata Mill., while cluster 5 includes mistletoe extracts from Crataegus monogyna Jacq., Fraxinus pensylvanica Marsh., Sorbus aucuparia L. and two subspecies of maple (Acer saccharinum L. and Acer platanoides L.). Mistletoe extracts from apple trees (Malus domestica Borkh.) constitute a separate cluster 6. The extracts within a given cluster show similarities in the polyphenol profile and antioxidant activity.

The chemometric analysis shows that mistletoe derived from conifers (Viscum album subsp. abietis and Viscum album subsp. austriacum) is the most advantageous material in terms of the chemical composition and antioxidant activity.

As shown by the available literature data, the analysis of phenolic acids in mistletoe from different the host trees has been an object of scientific interest. Qualitative studies of phenolic acids were carried out by Krzaczek (1977) [26] and quantitative studies were conducted by Łuczkiewicz et al. (2001) [28], Vicas et al. (2011) [33], and Stefanucci et al. (2020) [34]. Flavonoid aglycones were studied by Haas et al. (2003) [35], Vicas et al. (2011) [33], and Stefanucci et al. (2020) [34]. The chemical composition of mistletoe was the subject of some publications, but these studies in most cases were focused on Viscum species without specifying the host trees from which the plant material was collected. A comparison of the present findings and the literature results of studies of the same mistletoe host tree is shown in Table 8. 
Table 8. Summary and comparison of the qualitative results of phenolic acids and flavonoid aglycones of mistletoe leaf extracts obtained in this study and included in the literature. Marking: "+"—compound present in the tested sample; "-" no presence in the tested sample; "NT"-not tested.

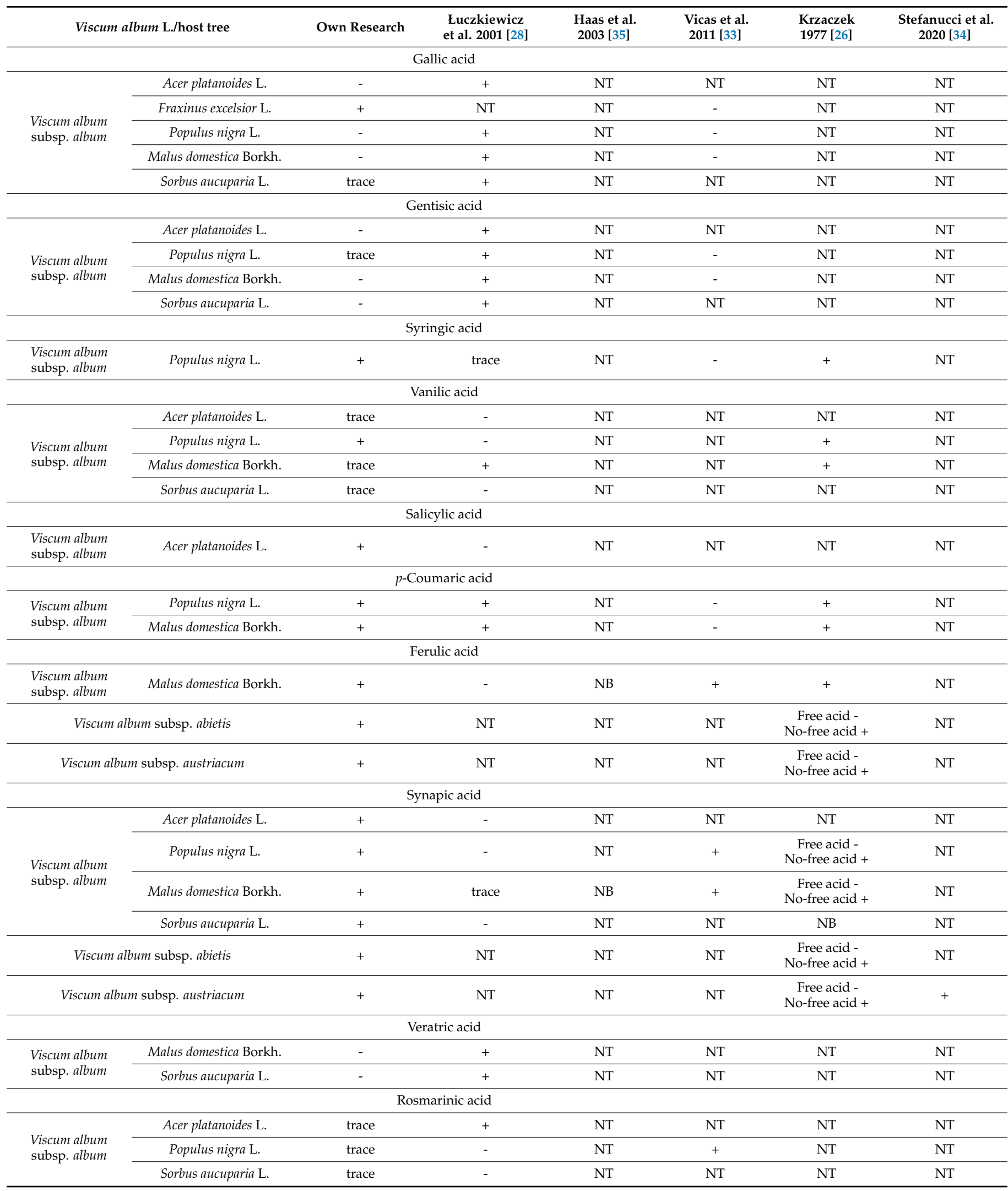


Table 8. Cont.

\begin{tabular}{|c|c|c|c|c|c|c|c|}
\hline \multicolumn{2}{|c|}{ Viscum album L./host tree } & Own Research & $\begin{array}{l}\text { Łuczkiewicz } \\
\text { et al. } 2001[28]\end{array}$ & $\begin{array}{l}\text { Haas et al. } \\
2003 \text { [35] }\end{array}$ & $\begin{array}{l}\text { Vicas et al. } \\
2011 \text { [33] }\end{array}$ & $\begin{array}{l}\text { Krzaczek } \\
1977 \text { [26] }\end{array}$ & $\begin{array}{l}\text { Stefanucci et al. } \\
2020 \text { [34] }\end{array}$ \\
\hline \multicolumn{8}{|c|}{ Quercetin } \\
\hline \multirow{2}{*}{$\begin{array}{l}\text { Viscum album } \\
\text { subsp. album }\end{array}$} & Populus nigra L. & - & NT & NT & + & NT & NT \\
\hline & Fraxinus excelsior $\mathrm{L}$. & - & NT & NT & + & NT & NT \\
\hline \multicolumn{8}{|c|}{ Kaempferol } \\
\hline $\begin{array}{l}\text { Viscum album } \\
\text { subsp. album }\end{array}$ & Fraxinus excelsior L. & - & NT & NT & + & NT & NT \\
\hline \multicolumn{8}{|c|}{ Naringenin } \\
\hline Viscum & subsp. abietis & + & NT & - & NT & NT & NT \\
\hline Viscum all & ubsp. austriacum & + & NT & NT & NT & NT & + \\
\hline \multicolumn{8}{|c|}{ Rhamnetin } \\
\hline Viscum & I subsp. abietis & - & NT & + & NT & NT & NT \\
\hline Viscum alt & ubsp. austriacum & + & NT & - & NT & NT & NT \\
\hline \multicolumn{8}{|c|}{ Isorhamnetin } \\
\hline Viscum all & ubsp. austriacum & + & NT & - & NT & NT & + \\
\hline \multicolumn{8}{|c|}{ Rhamnazin } \\
\hline Viscum & l subsp. abietis & - & NT & + & NT & NT & NT \\
\hline Viscum all & ubsp. austriacum & + & NT & - & NT & NT & NT \\
\hline
\end{tabular}

The differences in the occurrence of phenolic acids and flavonoid aglycones in the $V$. album species may depend on many factors that should be examined more closely. One of the most likely causes of the qualitative differences is the method used to determine the content of the tested compounds. Łuczkiewicz et al. (2001) and Vicas et al. (2011) determined the compounds using high-performance liquid chromatography, while HPLC in this study was coupled with mass spectrometry, which significantly increased the accuracy and sensitivity of the determination of phenolic substances. In the LC-ESI-MS/MS method, the tested compounds are identified based on not only the retention time but also fragmentation ions. In our research, many other unidentified compounds were found during the analysis, with similar or very similar retention times and even fragmentation ion masses, which indicates a huge diversity in the chemical composition of mistletoe. The influence of other factors should also be investigated, e.g., the time and place of harvesting the plant material, the method of preparation of samples for analysis, the conditions of analysis, and the detectability and content of individual phenolic compounds.

\section{Materials and Methods}

\subsection{Plant Metarial}

To determine the impact of the harvest time on the content and chemical composition of plant material, mistletoe herb (leaves and stems) was collected every four weeks from ten host trees of Populus nigra L. located close to Olszowiec, Poland (51o21" N; 22o13" E) from February 2016 to April 2017.

To determine the effect of the harvesting place on the composition and antioxidant activity of the plant material, mistletoe herb was harvested from ten apple trees (Malus domestica Borkh.) in one orchard from five different places located close to the Lublin region (Poland) in November 2017. Details are shown in Supplementary Table S1.

For analysis of the impact of the host tree species on the chemical composition and antioxidant activity of the plant material, mistletoe leaves and stems were harvested from eleven different host trees: V. album subsp. album from Populus nigra L., Populus nigra L. 'Italica', Fraxinus pennsylvanica Marsh., Fraxinus exscelsior L., Acer platanoides L., Acer saccharinum L., Malus domestica Borkh., Sorbus aucuparia L., Tilia cordata Mill.; V. album subsp. austriacum from Pinus sylvestris L., and V. album subsp. abietis from Abies alba Mill. growing close to the Lublin region (Poland) in winter 2017/2018. In all cases, the plant material from the same host trees was averaged, air-dried at room temperature, and powdered. 


\subsection{Extraction Method}

The method of mistletoe extraction was optimized and described previously by Pietrzak et al. (2014).

An amount of $5 \mathrm{~g}$ of powdered herb mistletoe (leaves and stems) was extracted using accelerated solvent extractions (ASE). Accelerated solvent extractions ( 3 times for $15 \mathrm{~min}$ each) were conducted in the ASE 150 system from Dionex Corporation (Sunnyvale, CA, USA) at $40{ }^{\circ} \mathrm{C}$ with $80 \%$ methanol concentrations.

In all cases, the extracts obtained were filtered, evaporated to dryness under vacuum, and lyophilized in the Free Zone 1 apparatus (Labconco, Kansas City, KS, USA). The residue was weighed and redissolved in the same solvent as that used for extraction to obtain stock solutions with a suitable concentration.

All samples were prepared in triplicate.

\subsection{Total Phenolic (TPC) and Flavonoid Content (TFC)}

The total phenolic content (TPC) and total flavonoid content (TFC) were determined using 96-well transparent microplates (Nunclon. Nunc. Roskilde, Denmark) and an Infinite Pro 200F microplate reader (Tecan Group Ltd., Männedorf, Switzerland).

The analysis of total phenolic content was carried out using the modified FolinCiocalteu method described earlier by Olech et al. (2012) [36]. Absorbance was read at $680 \mathrm{~nm}$ after 20-min incubation. TPC was determined using a standard curve prepared for gallic acid. The results were expressed as $\mathrm{mg}$ of gallic acid per $1 \mathrm{~g}$ of dry weight of plant material (GAE-gallic acid equivalent).

The total flavonoid content (TFC) was determined according to the modified Lamaison and Carret (1990) method [37,38]. The absorbance was measured at $430 \mathrm{~nm}$ after 30-min incubation against a blank methanol-containing solution instead of the test sample. The results were expressed as $\mathrm{mg}$ quercetin $(\mathrm{Q})$ per $1 \mathrm{~g}$ of dry extract.

\subsection{Antioxidant Activity Analysis}

The antioxidant assay was determined with the DPPH ${ }^{\bullet}$ (2,2-diphenyl-1-picrylhydrazyl) method with some modifications $[37,39]$. The absorbance was measured at $517 \mathrm{~nm}$ after a 30-min incubation. The inhibition curves were prepared and $\mathrm{EC}_{50}$ values, defined as the amount of the antioxidant necessary to decrease the initial $\mathrm{DPPH}^{\bullet}$ concentration by $50 \%$, were determined.

The results were expressed as $\mathrm{mg}$ of dry extract per $1 \mathrm{mg}$ of $\mathrm{DPPH}^{\bullet}$.

The antiradical activity was assayed using an improved $\mathrm{ABTS}^{+\bullet}$ decolorization assay with modifications [40,41]. The absorbance was measured at $734 \mathrm{~nm}$ after a 6-min incubation. The ability of the extract to quench the $\mathrm{ABTS}^{+} \bullet$ free radical was determined using the following Equation (1):

$$
\text { Scavenging } \%=[(\mathrm{AC}-\mathrm{AA}) / \mathrm{AC}] \cdot 100
$$

where $\mathrm{AC}$ is the absorbance of the control and AA is the absorbance of the sample.

The results were expressed as Trolox equivalent antioxidant capacity (TEAC) (mM of Trolox per $g$ of dry extract) based on their $\mathrm{EC}_{50}$ values.

The Oxygen Radical Absorbance Capacity (ORAC) assay was performed according to the modified method developed by Dienaite et al. (2020) [42,43].

The sample activity was expressed as $\mathrm{mM}$ of Trolox per $\mathrm{g}$ of dry extract.

All determinations were carried out using the Infinite Pro 200F microplate reader in triplicate. 


\subsection{LC-ESI-MS/MS Analysis}

\subsubsection{Chromatographic Conditions and Apparatus}

Phenolic acids and flavonoid aglycones were determined with reversed-phase highperformance liquid chromatography and electrospray ionization mass spectrometry (LC-ESI-MS/MS).

The Agilent 1200 Series HPLC system (Agilent Technologies, Santa Clara, CA, USA) equipped with a binary gradient solvent pump, a degasser, an autosampler, and a column oven connected to a 3200 QTRAP Mass spectrometer ((Sciex, Redwood City, CA, USA) was used.

The contents of phenolic acids and free flavonoid aglycones were determined with a simple and rapid method using liquid chromatography-electrospray ionization-tandem mass spectrometry. The compounds were separated at $25^{\circ} \mathrm{C}$ on a Zorbax SB-C18 column $(2.1 \times 50 \mathrm{~mm}, 1.8-\mu \mathrm{m}$ particle size; Agilent Technologies, Santa Clara, CA, USA).

The contents of phenolic acids were determined with the LC-ESI-MS/MS method described previously by Nowacka et al. (2014) [44] with some modifications.

The determination of flavonoid aglycones was carried out using the LC-ESI-MS/MS method described by Pietrzak et al. (2017) [45] with some modifications.

\subsubsection{Optimization of Parameters for the Quantitative Analysis}

The 3200 QTRAP MS/MS system and an electrospray ion source in the negative mode were used. The optimal mass spectrometer parameters were determined experimentally and were as follows for the analysis of flavonoid aglycones: curtain gas 20 psi, capillary temperature $500{ }^{\circ} \mathrm{C}$, nebulizer gas $30 \mathrm{psi}$, and negative ionization mode source voltage $-4500 \mathrm{~V}$. The following parameters were used for the analysis of phenolic acids: curtain gas $25 \mathrm{psi}$, capillary temperature $500^{\circ} \mathrm{C}$, nebulizer gas $60 \mathrm{psi}$, and negative ionization mode source voltage $-4500 \mathrm{~V}$.

Nitrogen was used as the nebulizer and collision gas. The quantitative analysis of the compounds was performed with multiple reaction monitoring (MRM), and Analyst 1.5 software (AB Sciex, Foster City, CA, USA) was used for data acquisition and analysis.

Multiple reaction monitoring (MRM) was used for the quantitative analysis of the compounds. The identified phenolic acids and flavonoid aglycones were quantified based on their peak areas and comparison with the calibration curve for the corresponding standards. Linearity ranges for the calibration curves were specified.

The limits of detection (LOD) and quantification (LOQ) for phenolic acids and flavonoid aglycones were determined at a signal-to-noise ratio of 3:1 and 10:1, respectively, by injecting a series of diluted solutions of known concentrations.

A summary of the optimized parameters for the quantitative analysis of phenolic acids and flavonoid aglycones determined by the LC-ESI-MS/MS method is presented in Supplementary Tables S2 and S3.

\subsection{Statistical Analysis}

All results were expressed as mean \pm standard deviation (SD) from three replications. Calculations were performed in STATISTICA 10.0 (StatSoft Poland, Cracow, Poland). The one-way ANOVA test followed by Tukey's post hoc test was used for statistical analysis of the differences among the obtained data. Significance was accepted at $p<0.05$.

The results of the spectrophotometric and LC-MS determinations were tested by chemometric analysis. Two methods of cluster analysis were applied: joining (tree clustering) and k-means clustering.

Calculations were performed in STATISTICA 10.0 (StatSoft).

\section{Conclusions}

In conclusion, the period, place of mistletoe harvest, and host tree species significantly affect the content of bioactive components and antiradical properties of extracts obtained from this plant material. 
The study has shown that the chemical profile and biological activity of the plant material are closely related to the climatic conditions. The best time to harvest mistletoe during the year is the autumn-winter period. Higher contents of flavonoids and polyphenols and high antioxidant activity were found for extracts obtained from plant material collected in cold weather, in the presence of snow, and in less sunshine.

The qualitative and quantitative composition and biological activity of mistletoe extracts, and hence their practical use, largely depend on the origin of the plant, i.e., the host tree from which the plant was harvested. The chemometric analysis showed that mistletoe collected from conifers (Viscum album subsp. abietis and Viscum album subsp. austriacum) is the most advantageous in terms of chemical and antioxidant activity.

The content of secondary plant metabolites is not stable. Factors such as the region/location effect and seasonal variations have an impact on their chemical composition, especially in parasitic plants. It should be emphasized that the present study is the first of such a comprehensive analysis of the influence of climatic factors, place of harvest, and host tree species on the quality of harvested Viscum herb. However, there is a need to continue long-term studies in this field.

Supplementary Materials: The following are available online, Figure S1: graphic division of mistletoe herb extracts from Malus domestica Borkh. for two clusters using the k-medium method (in terms of phenolic acids content and spectrophotometric analysis of TPC, TFC and antioxidant activities), Figure S2: the chromatogram in MRM mode of flavonoid aglycones in Viscum austriacum herb extract: 1- eriodictyol; 2- 3-O-methylquercetin; 3- quercetin; 4- naringenin; 5- kaempferol; 6-isorhamnetin; 7rhamnetin; 8- sakuranetin, Figure S3: the chromatogram in MRM mode of phenolic acids in Viscum abietis herb extract: 1- protocatechuic acid; 2- 4-hydroxybenzoic acid; 3- salicylic acid; 4- caffeic acid; 5syringic acid; 6- $p$-coumaric acid; 7-ferulic acid. Table S1: the harvesting place of mistletoe herb from apple trees (Malus domestica Borkh.), Table S2: summary of optimized parameters for the quantitative analysis of phenolic acids and flavonoid aglycones, Table S3: analytical parameters of LC-MS/MS quantitative method for determination of phenolic acids and flavonoid aglycones.

Author Contributions: Conceptualization, methodology W.P. and R.N., validation, formal analysis W.P., writing—original draft preparation, W.P.; writing—review and editing, R.N.; visualization, W.P. All authors have read and agreed to the published version of the manuscript.

Funding: This research received no external funding.

Institutional Review Board Statement: Not applicable.

Informed Consent Statement: Not applicable.

Data Availability Statement: Data sharing not applicable.

Conflicts of Interest: The authors declare no conflict of interest.

Sample Availability: Samples of the compounds are available from the authors.

\section{References}

1. Burdejova, L.; Moravcova, D.; Strouhalova, D.; Lunerova, K. Pressurized water extraction-The fast and efficient method for isolation of bioactive proteins from Viscum album leaves. J. Pharm. Biomed. Anal. 2021, 195, 113850. [CrossRef]

2. Garg, S.; Patil, U.K.; Shrivastava, T.P. Antimicrobial Potential Plant of Viscum articulum Brm. An Ethnomedicinal. Res. J. Pharm. Technol. 2013, 6, 649-651.

3. Marvibaigi, M.; Supriyanto, E.; Amini, N.; AbdulMajid, F.A.; Jaganathan, S.K. Preclinical and Clinical Effects of Mistletoe against Breast Cancer. BioMed Res. Int. 2014, 2014, 785479. [CrossRef]

4. Orhan, D.D.; Aslan, M.; Sendogdu, N.; Ergun, F.; Yesilada, E. Evaluation of the hypoglycemic effect and antioxidant activity of three Viscum album subspecies (European mistletoe) in streptozotocin-diabetic rats. J. Ethnopharmacol. 2005, 98, 95-102. [CrossRef]

5. Son, G.S.; Ryu, W.S.; Kim, H.Y.; Woo, S.U.; Park, K.H.; Bae, J.W. Immunologic response to mistletoe extract (Viscum album L.) after conventional treatment in patientswith operable breast cancer. J. Breast Cancer 2010, 13, 14-18. [CrossRef]

6. Shahaboddin, M.E.; Pouramir, M.; Moghadamnia, A.; Lakzaei, M.; Mirhashemi, S.M. Antihyperglycemic and antioxidant activity of Viscum album extract. Afr. J. Pharm. Pharmacol. 2011, 5, 432-436. [CrossRef]

7. Önay-Uçar, E.; Karagöz, A.; Arda, N. Antioxidant activity of Viscum album spp. album. Fitoterapia 2006, 77, 556-560. [CrossRef] 
8. Kwon, Y.-S.; Chun, S.-Y.; Kim, M.-K.; Nan, H.-Y.; Lee, C.; Kim, S. Mistletoe Extract Targets the STAT3-FOXM1 Pathway to Induce Apoptosis and Inhibits Metastasis in Breast Cancer Cells. Am. J. Chin. Med. 2021, 49, 487-504. [CrossRef]

9. Tröger, W.; Galun, D.; Reif, M.; Schumann, A.; Stanković, N.; Milićević, M. Viscum album [L.] extract therapy in patients with locally advanced or metastatic pancreatic cancer: A randomised clinical trial on overall survival. Eur J Cancer 2013, 49, 3788-3797. [CrossRef] [PubMed]

10. Simões-Wüst, A.P.; Hunziker-Basler, N.; Zuzak, T.J.; Eggenschwiler, J.; Rist, L.; Viviani, A. Long-lasting cytotoxic effects of a single application of aqueous extracts from dried Viscum album L. on bladder cancer cells in an in vitro system. Phytomedicine 2007, 14, S49.

11. Shakeel, M.; Trinidade, A.; Geider, S.; Ah-See, K.W. The case for mistletoe in the treatment of laryngeal cancer. J. Laryngol. Otol. 2014, 128. [CrossRef] [PubMed]

12. Seifert, G.; Jesse, P.; Laengler, A.; Reindl, T.; Lüth, M.; Lobitz, S.; Henze, G.; Prokop, A.; Lode, H.N. Molecular mechanisms of mistletoe plant extract-induced apoptosis in acute lymphoblastic leukemia in vivo and in vitro. Cancer Lett. 2008, 264, 218-228. [CrossRef] [PubMed]

13. Menke, K.; Schwermer, M.; Eisenbraun, J.; Schramm, A.; Zuzak, T.J. Anticancer effects of Viscum album Fraxini extract on medulloblastoma cells in vitro. Complement. Med. Res. 2021, 28, 15-22. [CrossRef] [PubMed]

14. Urech, K.; Schaller, G.; Jaeggy, C. Viscotoxins, mistletoe lectins and their isoforms in mistletoe (Viscum album L.) extracts Iscador-Analytical results on pharmaceutical processing of mistletoe. Arzneimittelforschung 2006, 56, 428-434. [PubMed]

15. Patel, S.; Gupta, G.K. Mistletoe lectin: A promising cancer therapeutic. In Chemical Drug Design; Gupta, G.K., Kumar, V., Eds.; Walter De Gruyter GmbH: Berlin, Germany, 2016. [CrossRef]

16. Kim, K.-W.; Yang, S.-H.; Kim, J.-B. Protein fractions from korean mistletoe (Viscum Album coloratum) extract induce insulin secretion from pancreatic beta cells. Evidence-Based Complement. Altern. Med. 2014, 2014, 703624. [CrossRef]

17. Adaramove, O.; Amanlou, M.; Habibi-Rezaei, M.; Pasalar, P.; Ali, M.M. Methanolic extract of African mistletoe (Viscum album) improves carbohydrate metabolism and hyperlipidemia in streptozotocin-induced diabetic rats. Asian Pac. J. Trop. Med. 2012, 5, 427-433. [CrossRef]

18. Ibegbulem, C.O.; Chikezie, P.C. Hypoglycemic properties of ethanolic extracts of Gongronema latifolium, Aloe perryi, Viscum album and Allium sativum administered to alloxan induced diabetic albino rats (Rattus norvegicus). J. Biol. Chem. Res. 2012, $29,16-25$. [CrossRef]

19. Valko, M.; Leibfritz, D.; Moncol, J.; Cronin, M.T.D.; Mazur, M.; Telser, J. Free radicals and antioxidants in normal physiological functions and human disease. Int. J. Biochem. Cell Biol. 2007, 39, 44-84. [CrossRef]

20. Evans, J.L.; Goldfine, I.D.; Maddux, B.A.; Grodsky, G.M. Oxidative stress and stress-activated signalling pathways: A unifying hypothesis of type II diabetes. Endocrine Rev. 2002, 23. [CrossRef]

21. Brasileiro, B.G.; Leite, J.P.V.; Casali, V.W.D.; Pizziolo, V.R.; Coelho, O.G.L. The influence of planting and harvesting times on the total phenolic content and antioxidant activity of Talinum triangulare (Jacq.) Willd. Acta Sci. Agron. 2015, 37, 249. [CrossRef]

22. Ochoa-Velasco, C.E.; Avila-Sosa, R.; Navarro-Cruz, A.R.; López-Malo, A.; Palou, E. Biotic and Abiotic Factors to Increase Bioactive Compounds in Fruits and Vegetables. In Food Bioconversion; Grumezescu, A.M., Holban, A.M., Eds.; Academic Press in an Imprint of Elsevier: Lonydn, UK, 2017. [CrossRef]

23. Blancquaert, E.; Oberholster, A.; Ricardo-da-Silva, J.M.; Alain, D. Effects of Abiotic Factors on Phenolic Compounds in the Grape Berry-A Review. S. Afr. J. Enol. Vitic. 2018, 40. [CrossRef]

24. Verma, N.; Shukla, S. Impact of various factors responsible for fluctuation in plant secondary metabolites. J. Appl. Res. Med. Aromat. Plants 2015, 2, 105-113. [CrossRef]

25. Mohiuddin, A.K. Impact of various environmental factors on secondary metabolism of medicinal plants. J. Pharm. Clin. Res. 2019, 7, 555704. [CrossRef]

26. Krzaczek, T. Badania farmakobotniczne podgatunków Viscum album L. IV. Kwasy i aminy. Ann. UMCS Sect. D 1977, 32, $281-292$.

27. Krzaczek, T.; Markowski, W. Volatile fatty acids in the subspecies Viscum album L. (In Polish). Ann. UMCS, Med. 1978, 33, 285-289.

28. Łuczkiewicz, M.; Cisowski, W.; Kaiser, P.; Ochocka, R.; Piotrowski, A. Comparative analysis of phenolic acids in mistletoe plants from various hosts. Acta Pol. Pharm. 2001, 58, 373-379.

29. Zuber, D. Biological flora of Central Europe: Viscum album L. Flora 2004, 199, 181-203. [CrossRef]

30. Schaller, G.; Urech, K.; Giannattasio, M. Cytotoxicity of Different Viscotoxins and Extractsfrom the European Subspecies of Viscum album L. Phytother. Res. 1996, 10, 473-477. [CrossRef]

31. Stypiński, P. Biology and ecology of mistletoe (Viscum album Viscaceae) in Poland; PAN: Kraków, Poland, 1997 ; pp. 1-117.

32. Ademiluyi, A.O.; Oboh, G. Antioxidant properties of methanolic extracts of mistletoes (Viscum album) from cocoa and cashew trees in Nigeria. Afr. J. Biotechnol. 2008, 7, 3138-3142.

33. Vicas, S.I.; Rugina, D.; Socaciu, C. Comparative study about antioxidant activities of Viscum album from different host trees, harvested in different seasons. J. Med. Plant. Res. 2011, 5, 2237-2244.

34. Stefanucci, A.; Zengin, G.; Llorent-Martinez, E.J.; Dimmito, M.P.; Valle, A.D.; Pieretti, S.; Ak, G.; Sinan, K.I.; Mollica, A. Viscum album L. homogenizer-assisted and ultrasound-assisted extracts as potential sources of bioactive compounds. J. Food Biochem. 2020, 44, e13377. [CrossRef]

35. Haas, K.; Bauer, M.; Wollenweber, E. Cuticular waxes and flavonol aglycones of mistletoes. Z. Naturforsch. C 2003, 58, 464-470. [CrossRef] 
36. Olech, M.; Nowak, R.; Los, R.; Rzymowska, J.; Malm, A.; Chruściel, K. Biological activity and composition of teas and tinctures prepared from Rosa rugosa Thunb. Cent. Eur. J. Biol. 2012, 7, 172-182. [CrossRef]

37. Pietrzak, W.; Nowak, R.; Olech, M. Effect of extraction method on phenolic content and antioxidant activity of mistletoe extracts from Viscum album subsp. abietis. Chem. Pap. 2014, 68, 976-982. [CrossRef]

38. Lamaison, J.L.C.; Carret, A. Teneurs en principaux flavonoides des fleurs de Cratageus monogyna Jacq et de Cratageus Laevigata (Poiret, D.C) en Fonction de la vegetation. Plant. Méd. Phytothér. 1990, 25, 12-16.

39. Brand-Williams, W.; Cuvelier, M.E.; Berset, C. Use of a free radical method to evaluate antioxidant activity. Lebensm.-Wiss. und-Technol. 1995, 28, 25-30. [CrossRef]

40. Re, R.; Pellegrini, N.; Proteggente, A.; Pannala, A.; Yang, M.; Rice-Evans, C. Antioxidant activity applying an improved ABTS_ radical cation decolorization assay. Free Radic. Biol. Med. 1999, 26, 1231-1237. [CrossRef]

41. Pieczykolan, A.; Pietrzak, W.; Nowak, R.; Pielczyk, J.; Łamacz, K. Optimization of extraction conditions for determination of Tiliroside in Tilia L. flowers using an LC-ESI-MS/MS method. J. Anal. Methods Chem. 2019, 1, 9052425. [CrossRef] [PubMed]

42. Dienaite, L.; Pukalskas, A.; Pukalskiene, M.; Pereira, C.V.; Matias, A.A.; Venskutonis, P.R. Phytochemical composition, antioxidant and antiproliferative activities of defatted sea buckthorn (Hippophaë rhamnoides L.) berry pomace fractions consecutively recovered by pressurized ethanol and water. Antioxidants 2020, 9, 274. [CrossRef] [PubMed]

43. Olech, M.; Łyko, L.; Nowak, R. Influence of Accelerated Solvent Extraction Conditions on the LC-ESI-MS/MS Polyphenolic Profile, Triterpenoid Content, and Antioxidant and Anti-lipoxygenase Activity of Rhododendron luteum Sweet Leaves. Antioxidants 2020, 9, 822. [CrossRef] [PubMed]

44. Nowacka, N.; Nowak, R.; Drozd, M.; Olech, M.; Los, R.; Malm, A. Analysis of phenolic constituents, antiradical and antimicrobial activity of edible mushrooms growing wild in Poland. LWT-Food Sci. Technol. 2014, 59, 689-694. [CrossRef]

45. Pietrzak, W.; Nowak, R.; Gawlik-Dziki, U.; Lemieszek, M.K.; Rzeski, W. LC-ESI-MS/MS identification of biologically active phenolic compounds in mistletoe berry extracts from different host trees. Molecules 2017, 22, 624. [CrossRef] [PubMed] 